\title{
CHARAKTERISTIKA PRACOVIŠŤ SDRUŽENÝCH V PROJEKTU CENTRA
}

\author{
Univerzita Karlova, Pedagogická fakulta \\ Ústav výzkumu a rozvoje vzdělávání
}

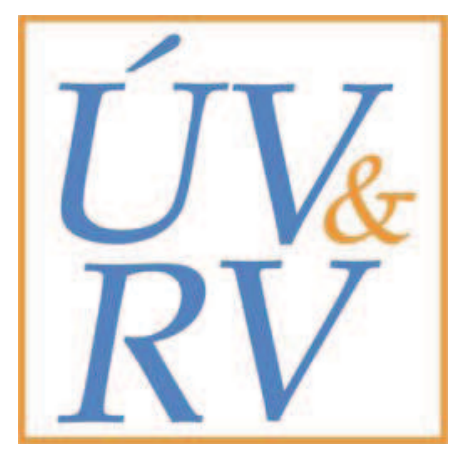

\section{Statut a profil ústavu}

V souladu se Statutem Pedagogické fakulty UK je Ústav výzkumu a rozvoje vzdělávání (dále ústav) pracoviště Univerzity Karlovy, Pedagogické fakulty, pro vědeckou, výzkumnou, vývojovou, expertní a vzdělávací činnost v oblasti pedagogických věd. Ústav se prioritně orientuje na základní výzkum školního vzdělávání. Realizuje komparativní a empirické výzkumy zaměřené na rozvoj vzdělávacího systému a řešení klíčových problémů českého vzdělávání v mezinárodním, zejména evropském, kontextu. Hlavním předmětem výzkumu jsou procesy a subjekty vzdělávání. Ústav přispívá $\mathrm{k}$ rozvoji pedagogických věd tvorbou nových poznatků, zejména v obecné, srovnávací, školní a vysokoškolské pedagogice. Součástí ústavu je Centrum evropských studií, které se zabývá vývojem modelů zavádění evropské dimenze do př́pravy učitelů a školního vzdělávání. Je referenčním a konzultačním pracovištěm pro školy, učitele a studenty.

\section{Hlavní linie činnosti ústavu}

Činnost ústavu je rozvíjena ve třech hlavních, vzájemně se prolínajících, liniích: vědeckovýzkumné, vývojové a vzdělávací. 
Vědeckovýzkumná činnost: Ústav realizuje výzkumné a vývojové projekty zaměřené zejména na školu jako sociální instituci, vzdělávací inovace a rozvoj učitelské profese. Řeší projekty základního a aplikovaného výzkumu, které mají pro rozvoj oboru a českého vzdělání zásadní význam. Realizuje empirické a komparativní výzkumy vzdělávání a vzdělávacích systémů, zejména průběžné analýzy vývoje českého vzdělávacího systému a jeho klíčových problémů, komparace zaměřené na budoucí scénáře rozvoje vzdělávání pro společnost vědění ve světě a v podmínkách ČR, trendy vzdělávací politiky a vzdělávací inovace $v$ EU se zvláštním zřetelem $k$ rozvoji ve stř̌ední Evropě. $V$ centru pozornosti výzkumných projektů je zajištování spravedlivého přístupu ke vzdělávání, hodnoty ve vzdělávání, vývoj školy jako sociální instituce a její vnitřní proměna, evaluace kvality školy, profesní rozvoj učitelů a kultura učitelských sborů. Ústav poskytuje expertizy a konzultace mezinárodním a národním institucím v oblasti vzdělávání, řizení školství, rozvoje vzdělávacích institucí a učitelské profese.

Vývojová činnost: Aplikace výsledků výzkumů jsou uplatňovány a ověřovány v rozvojových projektech, inovativních a podpůrných programech $\mathrm{v}$ oblastech, které jsou prioritní z hlediska potřeb praxe a reagují na aktuální problémy školního vzdělávání a vzdělávání učitelů $v$ ČR. Jedná se zejména o zavádění evropské dimenze do vzdělávání, školní inovace a kvalitu vzdělávání a profesního rozvoje učitelů. Ověřování těchto programů je spojeno s pilotním, eventuálně akčním a evaluačním výzkumem, aby byly vytvořeny předpoklady pro jejich zavedení do běžné praxe. Tuto činnost rozvíjí ústav ve vlastních projektech nebo prostřednictvím partnerství v projektech mezinárodních, ve spolupráci s fakultami připravujícími učitele, rezortními ústavy, řídicími školskými orgány na národní i regionální úrovni i př́mou spoluprací se školami. Pro rozvojové projekty získává ústav aktivně finanční podporu v evropských fondech a grantových programech. Tato podpora umožňuje realizaci projektů a vytváření flexibilních týmů, v nichž působí kromě kmenových pracovníků ústavu další externí spolupracovníci.

Vzdělávací činnost: Těžiště vzdělávací činnosti ústavu je v doktorském studiu oboru pedagogika. Ústav garantuje společné kurzy pro všechny specializace, které v doktorském studiu pod obor pedagogika na fakultě spadají, a přispívá tak výrazně ke koordinaci a evaluaci doktorského studia v oboru; školí rovněž doktorandy vlastní. Organizuje vědecké konference a semináře pro doktorandy a mladé vědecké pracovníky, poskytuje teoretické a metodologické konzultace $\mathrm{k}$ jejich studiu a projektům. Výrazný podíl ústavu v komisích pro doktorské zkoušky a obhajoby disertačních prací, zejména $\mathrm{v}$ roli oponentů, je regulérní součástí činnosti ústavu. Pro tyto účely je budováno $\mathrm{v}$ ústavu centrum doktorského studia a realizován rozvojový projekt na podporu jeho kvality. Ústav se také podílí na akreditovaných programech bakalářského a magisterského studia ve specializacích umožňujících využití výsledků jeho vědecké a výzkumné činnosti. Současně realizuje kurz pedagogiky pro zahraniční studenty $\mathrm{v}$ angličtině a připravuje pro ně studijní texty. Na vzdělávací činnosti fakulty se podílejí pracovníci ústavu také vedením seminárních, diplomových a bakalářských prací, předsednictvím v komisích pro rigorózní zkoušky, státní závěrečné zkoušky pro učitelství všeobecně vzdělávacích předmětů $\mathrm{z}$ pedagogiky a psychologie a pro závěrečné bakalářské zkoušky ze školského managementu. 


\section{Projekty řešené $v$ současnosti}

ם Centrum základního výzkumu školního vzdělávání. PedF UK a PedF MU. Řešitel - koordinátor: doc. PhDr. Eliška Walterová, CSc. 2006-2010.

口 Podpora rozvoje aktivit doktorského studia v oboru pedagogika. MŠMT ČR. Řešitel: doc. PhDr. Eliška Walterová, CSc. 2006.

口 Rizika a př́ležitosti přechodu ze základní školy na střední školu. GA ČR. Řešitel: doc. PhDr. Eliška Walterová, CSc. 2006-2008.

a Developing a sense of justice among disadvantaged students: the role of schools. EK - Socrates 6.1.2. Hlavní řešitel za ČR: Mgr. David Greger, Ph.D. 2005-2007.

口 Percepce spravedlivosti vzdělávacího systému u žákủ 8. ročníku povinné školní docházky a kritéria spravedlivosti jejich učitelů. GA AV. Řešitel: Mgr. David Greger, Ph.D. 2005-2006.

口 Zkvalitnění pedagogicko-psychologické přípravy budoucích učitelů. ESF - MŠMT. Řešitel: doc. PaedDr. Jaroslava Vašutová, Ph.D. 2005-2007.

口 Rozvoj sítě pražských inovujících škol. ESF - Hl. m. Praha. Řešitel: Mgr. Karel Starý. 2006-2008.

\section{Vybrané ukončené projekty}

\ Strukturace a kvalita doktorského studia v oboru pedagogika na Pedagogické fakultě UK. MŠMT ČR. Řešitel: doc. PhDr. Eliška Walterová, CSc. 2005.

- Rozvoj národní vzdělanosti a profesionalizace učitelů v evropském kontextu. VZ MŠMT ČR. Řešitel: doc. PhDr. Eliška Walterová, CSc. 1999 -2004.

口 N-LARGE EUROPE: Open Doors To A Broader European Dimension ERASMUS IP. Ǩešitel za ČR: PaedDr. Věra Ježková. 2003.

口 Evropská studia pro učitele a další pedagogické pracovníky. FRVŠ. Ǩešitel: PaedDr. Věra Ježková. 2001.

\section{Vybrané publikace}

WALTEROVÁ, E. a kol. Úloha školy v rozvoji vzdělanosti.1. a 2. díl. Brno : Paido, 2004. ISBN 80-7315-083-2.

VAŠUTOVÁ, J. Profese učitele v českém vzdělávacím kontextu. Brno : Paido, 2004. ISBN 80-7315-082-4.

SPILKOVÁ, V. a kol. Současné proměny vzdělávání učitelů. Brno : Paido, 2004. ISBN 80-7315-081-6.

Česká pedagogika: promèny a výzvy: Sborník k životnímu jubileu profesora Jiř́ho Kotáska.. WALTEROVÁ, E. (ed.). Praha : UK - PedF, 2004. ISBN 80-7290-169-9.

VAŠUTOVÁ, J. Strategie výuky ve vysokoškolském vzdělávání. Praha : UK-PedF, 2002. ISBN 80-7290-100-1.

Národní program rozvoje vzdělávání v České republice : Bílá kniha. KOTÁSEK, J. (ed). Praha : ÚIV - Tauris, 2001. ISBN 80-211-0372-8.

Rozvoj národní vzdělanosti a vzdělávání učitelů $v$ evropském kontextu : Výstupy řeše- 
ní za rok 2001. I. díl, Teoretické a komparativní studie. WALTEROVÁ, E. (ed.). Praha : UK- PedF, 2002. ISBN 80-7290-085-4. II. díl, Metody a výsledky empirických výzkumů. SPILKOVÁ, V.; VAŠUTOVÁ, J. (eds.). Praha : UK - PedF, 2002. ISBN 80-7290-090-0.

JEŽKOVÁ, V.; SYŘIŠTĚ, I.; CHALUPOVÁ, M. Evropská čítanka : pro učitele a studenty učitelství. Praha : UK - PedF, 2002. ISBN 80-7290-071-4.

WALTEROVÁ, E.; JEŽKOVÁ, V. Žijeme v Evropě : Průvodce evropskou terminologií pro učitele a studenty učitelství. 2. rozš. a přeprac. vyd. Praha : UK - PedF, 2000. ISBN 80-7290-022-6.

Aktuální informace o ústavu: www.pedf.cuni.cz/uvrv

Adresa: $\quad$ Myslíkova 7, 11000 Praha 1 (poštovní)

Vratislavova 13, Praha 2 (přechodně fyzická/skutečná)

Tel. $\quad 420-221900735$

420 - 221900530

Fax: $\quad 420-224947782$

E-mail: $\quad$ secretar@uvrv.pedf.cuni.cz 


\title{
MASARYKOVA UNIVERZITA, PEDAGOGICKÁ FAKULTA
}

\author{
Centrum pedagogického výzkumu
}

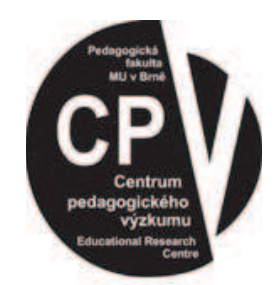

\section{Odborný profil a statut Centra pedagogického výzkumu PdF MU}

Centrum pedagogického výzkumu PdF MU (dále jen CPV) bylo zřízeno ke dni 1 . 7. $2003 \mathrm{~s}$ cílem posílit vědeckou a výzkumnou práci na PdF MU, a to zejména v oblasti pedagogiky a oborových didaktik. CPV sleduje obecnou problematiku pedagogické metodologie. $\mathrm{Z}$ konkrétních metodologických problémů jsou v popředí zájmu filozofické aspekty edukace, vztah vědecké a praktické pedagogiky, vztah obecné didaktiky a oborových didaktik, možnosti propojování kvantitativních a kvalitativních výzkumných metod a další.

CPV realizuje základní a aplikovaný výzkum, nejčastěji v rámci získaných grantových projektů. Vydává informační periodikum (Bulletin CPV) o aktuální výzkumné, oborově didaktické a pedagogické problematice. V rámci edice „Pedagogický výzkum v teorii a praxi“ garantuje vydávání sborníků a monografií k problematice pedagogického výzkumu. Buduje odbornou knihovnu k problematice pedagogické metodologie a pedagogického výzkumu. Pracovníci CPV navazují pracovní kontakty s domácími i zahraničními pracovišti, účastní se stáží a výměnných pobytů a iniciují výzkumné projekty v oblasti srovnávací pedagogiky.

CPV se podílí na zabezpečování doktorského studia $\mathrm{v}$ oboru pedagogika, a to organizováním pravidelných konferencí, seminářủ, konzultací a vedením disertačních prací. Jeho pracovníci se zapojují také do výuky pedagogické metodologie v bakalářských a magisterských i studijních programech. 


\section{Výzkumné aktivity CPV - řešené projekty}

Výzkumné aktivity CPV se realizují zejména $\mathrm{v}$ rámci řešení projektů a grantů, do nichž jsou pracovníci CPV zapojení. Jedná se jak o české (GAČR, MŠMT), tak o mezinárodní projekty (COMENIUS, ERASMUS).

- Ve spolupráci s Ústavem výzkumu a rozvoje vzdělávání PedF UK v Praze bylo k 1. 3. 2006 zahájeno řešení resortního projektu MŠMT ČR LC06046 Centrum základního výzkumu školního vzdělávání. Řešitel koordinátor: doc. PhDr. Eliška Walterová, CSc., řešitel za PdF MU: doc. PhDr. Jiří Němec, Ph.D. (2006-2010).

- Druhým rokem pokračuje řešení výzkumného záměru MSM 0021622421 Škola a zdraví pro 21. století. Řešitel: doc. PhDr. Evžen Řehulka, CSc. (2005-2010).

- Rovněž druhým rokem pokračuje práce na grantovém projektu GA ČR 406/05/0246 Obsahová dimenze kurikula základní školy. Řešitel: prof. PhDr. Josef Maňák, CSc. (2005-2007).

- K 1. 1. 2006 bylo zahájeno řešení projektu GA ČR 406/06/P037 Didaktická znalost obsahu jako klíčový koncept kurikulární reformy. Řešitel: PhDr. Tomáš Janík, Ph.D., M.Ed. (2006-2008).

- Mezinárodní spolupráce je podporována zapojením CPV do projektu COMENIUS 2.1 - IDENTITIES: From Identities in Europe to European Identities. Řešitel za ČR: PhDr. Tomáš Janík, Ph.D., M.Ed. (2004-2006).

- Dále projektem COMENIUS 2.1 - EIS.WEB - Europäische-innovative Schulentwicklung im World-Wide-Web Řešitel za ČR: PhDr. Tomáš Janík, Ph.D., M.Ed. (20052007).

\section{Výzkumné aktivity CPV - vybrané ukončené projekty}

- K 31. 12. 2004 bylo úspěšně ukončeno řešení projektu GA ČR 406/02/1247 Implicitní pedagogické znalosti a možnosti autoregulace procesu jejich rozvíjení. Řešitel: prof. PhDr. Vlastimil Švec, CSc. (2002-2004).

- K 31. 12. 2005 bylo ve spolupráci s katedrou pedagogiky PdF MU úspěšně ukončeno řešení projektu GA ČR 406/03/1347 Intervence do procesu rozvijení pedagogických dovedností studentů učitelství v průběhu jejich praxe na fakultní škole. Řešitel: PaedDr. Jan Štáva, CSc. (2003-2005).

\section{Vybrané publikace}

JANÍK, T.; MIKOVÁ, M. Videostudie: Výzkum výuky založený na analýze videozáznamů. Brno : Paido, 2006. ISBN 80-7315-127-8.

MAŇÁK, J.; KLAPKO, D. (ed.). Učebnice pod lupou. Brno : Paido, 2006. ISBN 807315-124-3.

MAŇÁK, J.; ŠVEC, Š.; ŠVEC, V. (ed.). Slovník pedagogické metodologie. Brno : Paido, MU, 2005. ISBN 80-210-3802-0.

MAŇÁK, J.; JANÍK, T. (ed.). Orientace české základní školy. Brno : MU, 2005. ISBN 80210-3870-5. 
JANÍK, T. Znalost jako klíčová kategorie učitelského vzdělávání. Brno : Paido, 2005. ISBN -7315-080-8

ŠVEC, V. Pedagogické znalosti učitele: teorie a praxe. Praha : ASPI, 2005. ISBN 807357-072-6.

ŠVEC, V. (ed.). Od implicitních teorií výuky k implicitním pedagogickým znalostem. Brno : Paido, 2005. ISBN 80-7315-092-1.

JANÍK, T.; MUŽÍK, V.; ŠIMONÍK, O. (ed.). Oborové didaktiky v pregraduálním učitelském studiu. Sborník z konference konané 13. - 14. září 2004 na PdF MU v Brně [CD-ROM]. Brno : MU, 2004. ISNB 80-210-3474-2.

MAŇÁK, J.; ŠVEC, V. (ed.). Cesty pedagogického výzkumu. Brno : Paido, 2004. ISBN 80-7315-078-6.

MAŇÁK, J.; ŠVEC, V. Výukové metody. Brno : Paido, 2003. ISBN 80-7315-039-5.

Aktuální informace o ústavu: http://www.ped.muni.cz/weduresearch/

Adresa: $\quad$ Poříčí 31, 60300 Brno

Tel: $\quad$ +420 $\quad$ + $\quad$ S49 493135 (sekretářka paní Marie Baráčková)

+420 549491677 (PhDr. Tomáš Janík, M.Ed., Ph.D.)

+420 549495490 (prof. PhDr. Josef Maňák, CSc.,

prof. PhDr. Vlastimil Švec, CSc.)

Fax: $\quad 420-224947782$

E-mail: $\quad$ tjanik@ped.muni.cz 


\section{Řešitelský tým}

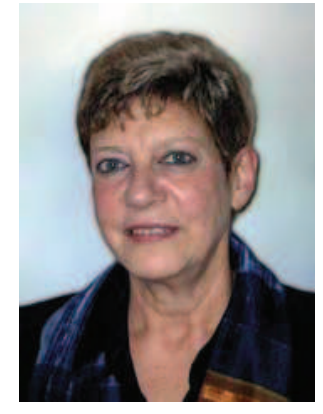

Doc. PhDr. Eliška Walterová, CSc., koordinátorka projektu. Pracuje od roku 1990 na Pedagogické fakultě UK, od roku 1998 je ředitelkou Ústavu výzkumu a rozvoje vzdělávání. Hlavními oblastmi jejího výzkumného zájmu a publikační činnosti jsou školní vzdělávání, kurikulum, evropská studia, srovnávací pedagogika, metodologie a terminologie pedagogiky. Byla řešitelkou několika národních projektů vztahujících se ke kurikulární reformě a evropské dimenzi ve vzdělávání, členkou týmu připravujícího Bílou knihu. Vedla výzkumný záměr Rozvoj národní vzdělanosti a profesionalizace učitelů v evropském kontextu (1999-2004), nyní je koordinátorkou a řešitelkou projektu Centrum základního výzkumu školního vzdělávání.

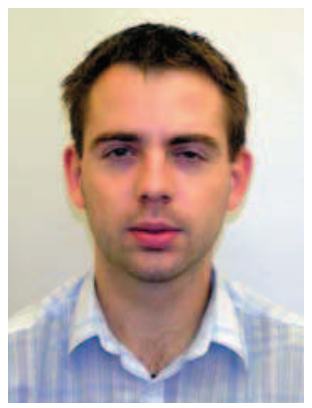

Mgr. Karel Černý je výzkumným pracovníkem v Ústavu výzkumu rozvoje vzdělávání Pedagogické fakulty UK, vzděláním sociolog, nyní v doktorském studiu oboru pedagogika. Zaměřuje se na výzkum vzdělávacích potřeb sociálních skupin a zajištování spravedlivosti ve vzdělávání.

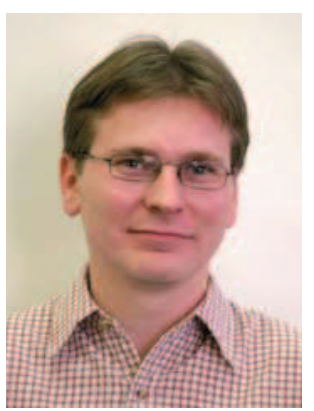

Mgr. David Greger, Ph.D., působí jako vědecký pracovník na Pedagogické fakultě UK v Praze, v Ústavu výzkumu a rozvoje vzdělávání. Věnuje se především oblastem vzdělávací politiky a srovnávací pedagogiky, z tematického hlediska se specializuje na otázku spravedlivosti a kvality ve vzdělávání a na otázky kurikula a jeho transformace - zejména na výzkumy učebnic.

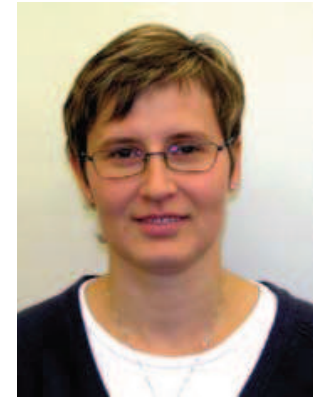

Mgr. Andrea Gröschlová působí jako doktorandka na Pedagogické fakultě UK, v Ústavu výzkumu a rozvoje vzdělávání. Ve svém studiu se věnuje srovnávací pedagogice a vzdělávací politice, $z$ tematického hlediska se specializuje zejména na problematiku evropské dimenze ve školním vzdělávání. 

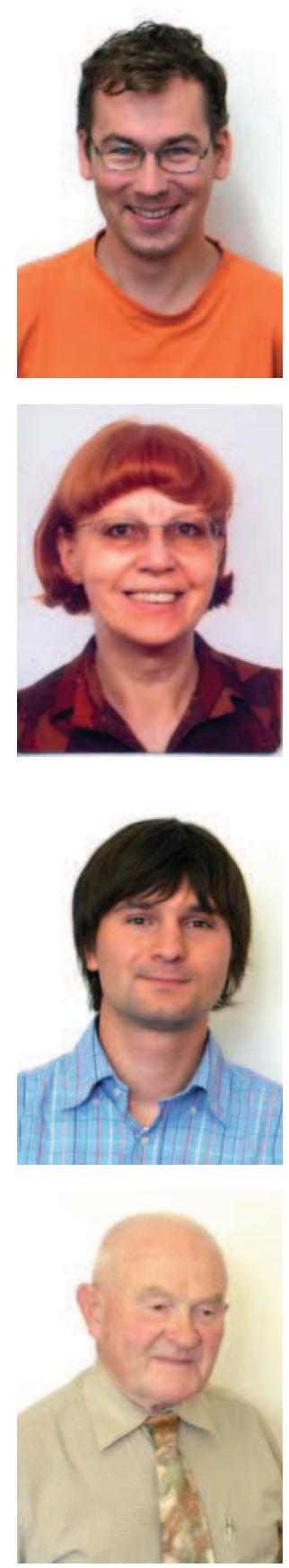

PhDr. Tomáš Janík, Ph.D., M.Ed., pracuje v Centru pedagogického výzkumu na Pedagogické fakultě $M U$ v Brně. Zaměřuje se na problematiku didaktického výzkumu a výzkumu kurikula. Předmětem jeho odborného zájmu jsou také otázky související se vzděláváním učitelů.

PaedDr. Věra Ježková pracuje na Pedagogické fakultě UK od roku 1977. Do roku 1989 působila v oblasti výchovného poradenství; od roku 1990 se předmětem jejího zájmu stala srovnávací pedagogika a evropská studia. V současné době pracuje jako vědecká pracovnice v Ústavu výzkumu a rozvoje vzdělávání. Předmětem jejího zájmu je zvláště německá jazyková oblast a problémy jazykového vzdělávání v multikulturní Evropě.

Mgr. Petr Knecht je studentem doktorského studijního programu pedagogika na Pedagogické fakultě MU v Brně. V roli doktoranda spolupracuje s Centrem pedagogického výzkumu této fakulty. Na částečný úvazek pracuje jako učitel na základní škole. Orientuje se zejména na výzkum učebnic a na problematiku didaktiky geografie.

Prof. PhDr. Josef Maňák, CSc., působil od roku 1960 na Filozofické fakultě UP v Olomouci, od roku 1967 na Pedagogické fakultě MU v Brně. Po roce 1989 na této fakultě zastával funkci proděkana, vedoucího katedry pedagogiky, nyní vede Centrum pedagogického výzkumu. Jeho hlavním oborem je obecná didaktika, kterou spojuje s aktuální problematikou současné školy. Jeho celoživotními tématy jsou problémy výukových metod, pedagogického výzkumu, otázky aktivity, samostatnosti a tvořivosti žáků a jiné. 


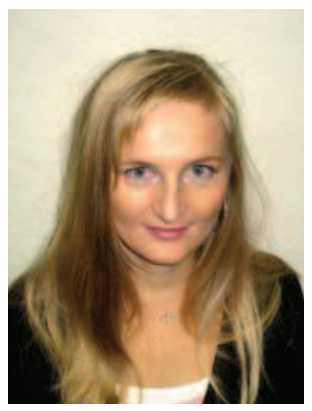

PhDr. Marcela Miková, Ph.D. působí na Katedře společenských věd Fakulty sportovních studií MU a v Centru pedagogického výzkumu Pedagogické fakulty MU v Brně. Zaměřuje se na problematiku pedagogické komunikace a interakce a dalšího vzdělávání učitelů.

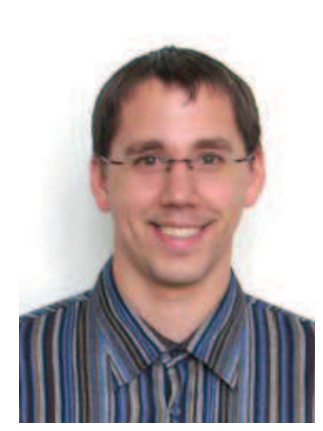

Mgr. Petr Najvar působí v Centru pedagogického výzkumu na Pedagogické fakultě MU v Brně. Na katedře anglického jazyka a literatury této fakulty vede semináře zaměřené na anglickou výslovnost. Je studentem doktorského studijního programu pedagogika na této fakultě. Odborně se zaměřuje na problematiku rané výuky cizích jazyků a na další otázky z oblasti lingvodidaktiky.

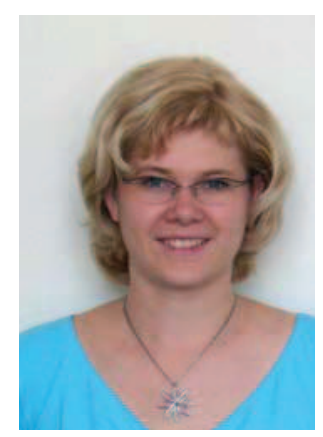

Mgr. Veronika Najvarová působí v Centru pedagogického výzkumu na Pedagogické fakultě MU v Brně. Je studentkou doktorského studijního programu pedagogika na této fakultě. Svůj odborný zájem zaměřila na oblast gramotnosti, zejména pak gramotnosti čtenářské. Zabývá se problematikou osvojování čtenářských dovedností a využivání čtenářských strategií žáky prvního stupně základní školy.

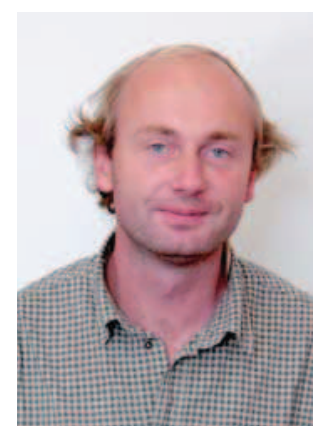

Doc. PhDr. Jiří Němec, Ph.D., je vedoucím Katedry sociální pedagogiky na Pedagogické fakultě MU v Brně a řešitelem projektu Centrum základního výzkumu školního vzdělávání na této fakultě. Výzkumně se orientuje na problematiku vzdělávání sociálně znevýhodněných žáků, tvořivosti a hry. $\mathrm{V}$ pedagogické oblasti se zaměřuje na výuku pedagogické a sociálně pedagogické metodologie, sociální pedagogiku a pedagogiku volného času. 


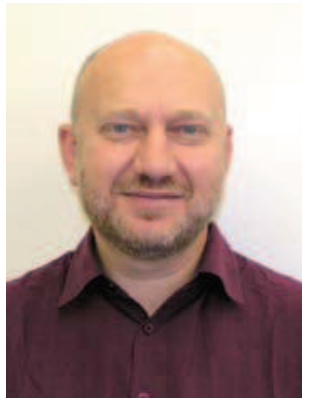

Mgr. Karel Starý, Ph.D. působí jako vědecký pracovník na Pedagogické fakultě UK v Praze, v Ústavu výzkumu a rozvoje vzdělávání. Více než patnáct let pracoval na základní škole a gymnáziu jako učitel dějepisu a českého jazyka. V současnosti se zabývá školní didaktikou a zaměřuje se na výzkum školního vzdělávání, zejména na efektivní výukové strategie a pedagogické hodnocení.

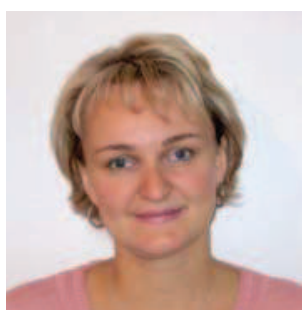

Mgr. Květa Suchánková působí jako interní doktorandka na Pedagogické fakultě UK v Ústavu výzkumu a rozvoje vzdělávání. Výzkumně se zaměřuje na analýzu činností učitele ve třídě a $\mathrm{v}$ prostředí školy.

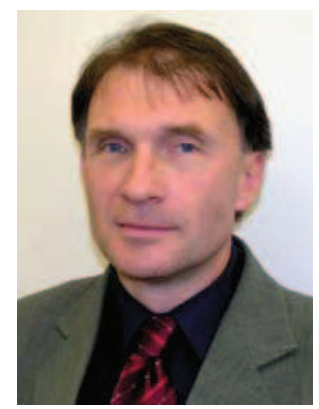

Doc. PhDr. Petr Urbánek, PhD. se zabývá výzkumem učitelské profese, kulturou učitelských sborů, rolemi a činnostmi učitelů $\mathrm{v}$ prostředí školy. $\mathrm{Na}$ řešení projektu participuje jako externista, jeho kmenovým pracovištěm je Pedagogická fakulta Technické univerzity Liberec.

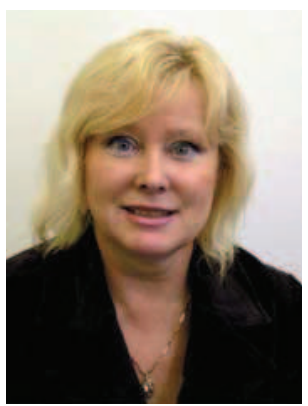

Doc. PaedDr. Jaroslava Vašutová, PhD. pracuje na Pedagogické fakultě UK od roku 1990, od roku 1998 je zástupkyní ředitelky Ústavu výzkumu a rozvoje vzdělávání. Hlavní oblastí její výzkumné a publikační činnosti je vysokoškolská pedagogika, učitelská profese a vzdělávání učitelů. V současné době vede rozvojový projekt ESF zaměřený na zkvalitňování pedagogicko-psychologické príípravy učitelů.

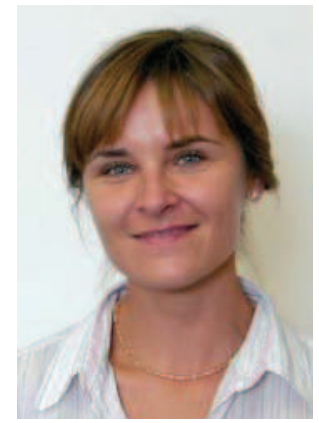

Mgr. et Mgr. Kateřina Vlčková, Ph.D. působí od roku 2001 na Katedře pedagogiky Pedagogické fakulty MU v Brně, v letech 2005-2006 jako odborný asistent, od roku 2006 pracuje v Centru pedagogického výzkumu této fakulty. Zaměřuje se na metodologii pedagogiky, zejména na empirický kvantitativní výzkum, zkoumá oblast strategií učení cizímu jazyku. Zabývá se také srovnávací pedagogikou (školské systémy, vzdělávací výsledky) a vzdělávací politikou. 